\title{
Analytical Methods of Size Distribution for Organic Matter in Water and Wastewater
}

\author{
H.K. Shon ${ }^{1}$, Seung-Hyun Kim ${ }^{2 *}$, Laszlo Erdei ${ }^{1}$, Saravanamuthu Vigneswaran ${ }^{1}$ \\ ${ }^{1}$ Faculty of Engineering, University of Technology, Sydney, Australia \\ ${ }^{2}$ Civil Engineering Department, Kyungnam University, 631-701 Wolyoung-dong, \\ Masan, Korea \\ * The author to whom all correspondence should be addressed. Email: shkim@kyungnam.ac.kr
}

\begin{abstract}
Organic matter (OM), such as natural organic matter (NOM) in surface waters, and effluent organic matter (EfOM) in wastewaters causes many problems. For example, color, taste and odor derogate potable water quality, while the presence of endocrine disrupting substances and the formation of disinfectant byproducts (DBPs) are public health concerns. Over the years various analytical methods have been developed to characterize organic matter in natural and wastewaters. However, it remains difficult to determine the properties and characteristics of various OM constituents. Since all OM components in water have their own specific sizes, size distribution is a useful analytical tool to characterize complex OM. The results also enable the better interpretation of experimental results, the determination of future research directions, and the evaluation of the progress of investigations. This review presents the common analytical size distribution methods used to characterize OM present in waters and wastewaters.
\end{abstract}

\section{Introduction}

NOM originates from the contact of water with dead and living organic matter in the hydrologic cycle, and is a fundamental component of aquatic ecosystems. Organic matter has important roles in the treatment of waters and wastewaters. It is one a major pollutant 
which produces harmful by-products with oxidants, increases chemical costs and deteriorates product water quality in the reticulation network.

While many previous researches have dealt with characteristics of NOM in surface waters, there are much fewer studies available on EfOM in biologically treated sewage effluent (BTSE). This may be due to the diverse, very complex composition of EfOM which varies from source to source and from season to season. However, with growing concerns related to wastewater discharges, new EfOM characterisation methods have been envisaged. EfOM consists of NOM, soluble microbial products (SMPs), persistent organic matter (POP), emerging pollutants such as endocrine disrupting chemicals (EDCs) and pharmaceuticals and personal care products (PPCPs). SMPs are a by-product of biological treatment, while POPs, EDCs and PPCPs originate from the use of synthetic organic matter (SOM) in daily life. The presence of these harmful chemicals in drinking water, even in trace amounts, is becoming a major concern, thus it is imperative to study the characteristics of EfOM in BTSE.

Aquatic NOM and EfOM are responsible for several problems in water, including color, taste, odor, increased chemical disinfectant demand and formation of DBPs. With the increasingly recognized importance of NOM and EfOM new analytical methods have been developed to determine the organic content of natural and wastewaters. Nonetheless, it still remains difficult and challenging to measure the properties of many organic constituents present in various waters.

The analytical methods for different OMs are divided into two broad groups: i) those are which measure gross concentrations of OM greater than about $1 \mathrm{mg} / \mathrm{L}$ and ii) those are which measure trace concentrations in the range of nano- and micro sizes (Tchobanoglous and Burton, 1991). The characterization of OM can also be classified into two categories: i) traditional analyses and ii) advanced analytical methods (Her, 2002). Most chemicals and also the physical characteristics of OM are normally analyzed with traditional methods (e.g., light absorptivity, DOC concentration, aromaticity, fluorescence, XAD fractionation) due to the difficulty and higher cost of detailed structure analysis. The advanced analytical approaches include nuclear magnetic resonance (NMR), gas chromatography and mass 
spectrometry (GC/MS), and attenuated total reflection-Fourier transform infrared spectroscopy (ATR-FTIR). These methods give more detailed information to characterize OM.

All OM constituents in water have their own specific sizes therefore size distribution is a useful analytical tool to characterize complex OM. Since 1950 a number of researchers have cited information of size distribution ( $\mathrm{Xu}, 2000)$. Size distribution has become an indispensable measurement in research and many projects depend on information obtained from such examinations. The main objective of this paper is to present common analytical methods and their characteristics. Information on size distribution of OM gives a number of advantages: i) a more fundamental understanding of the complex interactions that occur in the unit operations and treatment process, ii) better process selection and evaluation to develop more effective treatment techniques and iii) determination of MW cut-off (MWCO) for targeted pollutants in membrane separation processes. Therefore, it is essential to classify the analytical methods of size distribution to identify detailed OM.

\section{Constituents of $\mathbf{O M}$}

Figures 1 and 2 show typical organic compounds present in surface water and BTSE. Painter (1973) and Levine et al. (1985) reported that organic contaminants range in size from less than $0.001 \mu \mathrm{m}$ to well over $100 \mu \mathrm{m}$. While both surface water and BTSE include similar constituents, a significant difference is SMP and SOM levels (Shon et al., 2006). In BTSE, SMP and SOM are preferentially present due to the origin of water and the biological treatment method involved. OM can be divided into dissolved organic carbon (DOC) and particulate organic carbon (POC) categories. Unfortunately, there is no commonly accepted understanding of the division size. For example, Levine et al. (1985) suggested $0.1 \mu \mathrm{m}$ as the cut line, Metcalf and Eddy (1991) $1 \mu \mathrm{m}$, while Malpei et al. (1997) $0.45 \mu \mathrm{m}$. In this paper a $0.45 \mu \mathrm{m}$ of cut line is considered because it is perhaps the most widely used in the literature.

POC includes zooplankton, algae, bacteria, and debris organic matter from soil and plants, and usually represents less than $10 \%$ of total OM. In water treatment POC is lesser concern 
than DOC because solid-liquid separation processes can remove it relatively easily. DOC is more difficult to deal with, it can impart many adverse effects on water quality, and so it remains in the focus of this paper.

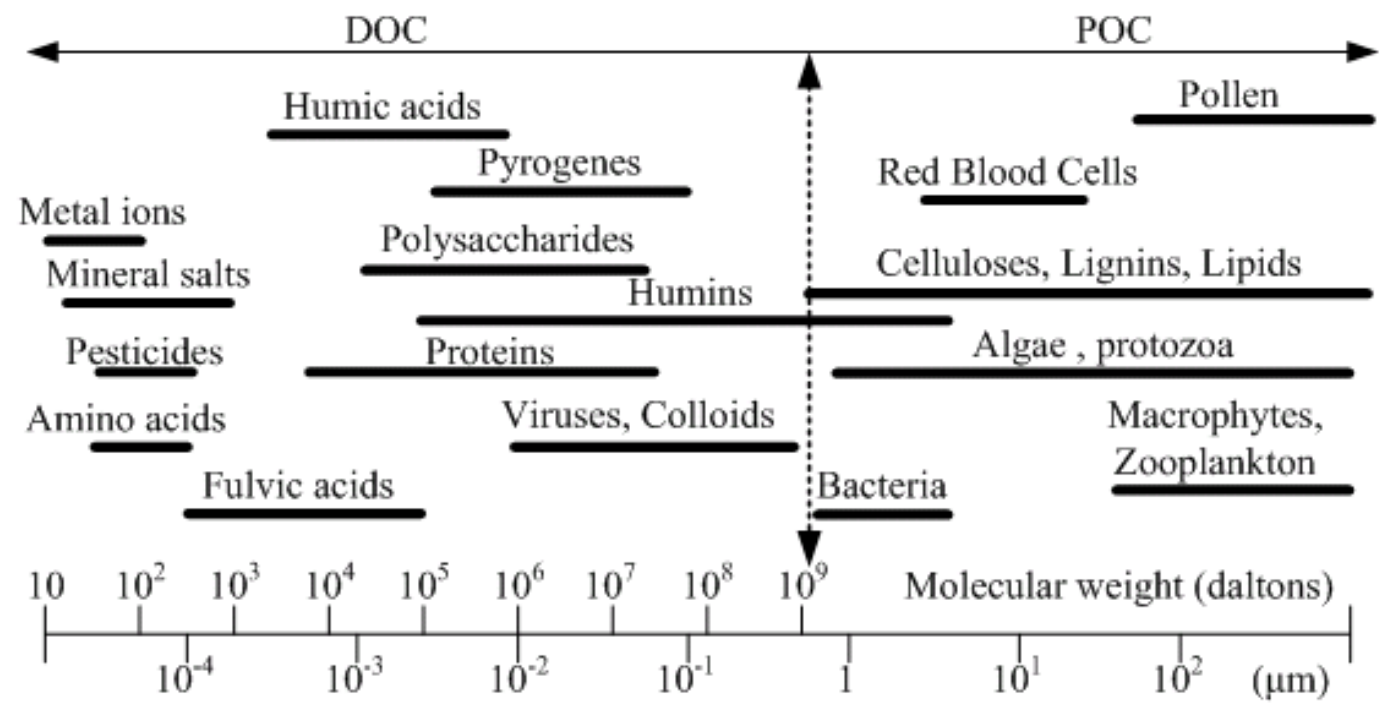

Figure 1 Typical organic constituent in surface water and their size ranges (adapted from Thurman, 1985 and Schafer, 2001).

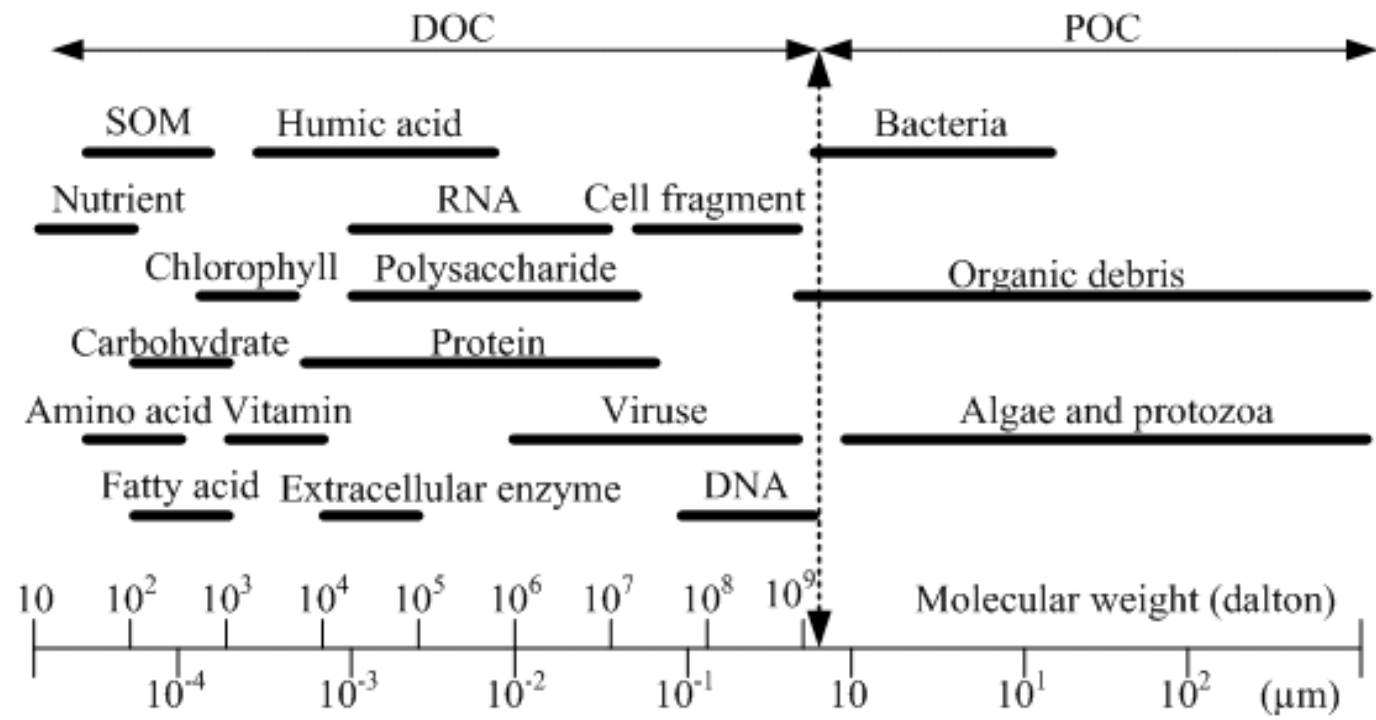

Figure 2 Typical organic constituents in BTSE and their size ranges (adapted from Levine et al., 1985; Leenheer and Croue, 2003).

The major macromolecules are polysaccharides, proteins, lipids and nucleic acids. DOC in the 1,000 to $1,000,000$ Da molecular weight (MW) range usually includes humic and fulvic 
acids. DOC with MW smaller than 1,000 Da mostly includes carbohydrates, amino acids (AA), vitamins, and chlorophyll. POPs, EDCs, and PPCPs such as dichloro-diphenyltrichloroethane (DDT), polychlorinated biphenyl (PCB) and other toxic substances of public health significance consist of low MW compounds (Stull et al, 1996; Pempkowiak and Obarska-Pempkowiak, 2002; Leenheer and Croue, 2003).

\section{Overview of Size Distribution}

The two common units used to denote OM sizes are nm and Da. However, the conversion between these units is difficult due to the differences in organic geometric structures. Table 1 presents a practical conversion, based on Shon et al. (2006b), noting that other conversion methods are also available in the literature (Lentsch et al., 1993; Bowen and Mohammad, 1998; Singh et al., 1998; Combe et al., 1999).

Table 1 Conversion between nm and Da units

\begin{tabular}{cc}
\hline Size $(\mathrm{Da})$ & Size $(\mathrm{nm})$ \\
\hline $500^{*}$ & 0.39 \\
$1,000^{*}$ & 0.50 \\
$5,000^{*}$ & 0.85 \\
$7,000^{*}$ & 0.95 \\
$10,000^{*}$ & 1.1 \\
$20,000^{*}$ & 1.3 \\
100,000 & 10 \\
500,000 & 50 \\
\hline
\end{tabular}

* The equation used to compute the size is: $\operatorname{Size}(\mathrm{nm})=\frac{0.1 *(M W)^{0.3321}}{2}$

Figure 3 shows analytical methods and their range of application which are used to determine size distribution of OM. Evidently, alternative methods exists for both POC and DOC to determine size distributions in given ranges. For example, POC sizes can be determined by scanning electron microscopy (SEM), sedimentation, centrifugation, sieve, 
membrane filter technique and light scattering method. DOC can be analyzed by highpressure size exclusion chromatograms (HPSEC), gel filtration, flow field flow fractionation (flow FFF), and ultrafiltration technique.

The conventional methods involved in POC size determination, such as sieve analysis, sedimentation analysis, centrifugation and membrane filter technique, are gradually being replaced by non-invasive methods which are based on light-matter interaction. In the case of DOC the conventional methods are ultrafiltration and gel filtration, which have been further developed to HPSEC and/or substituted by flow FFF.

Light microscopy

Scanning electron microscopy
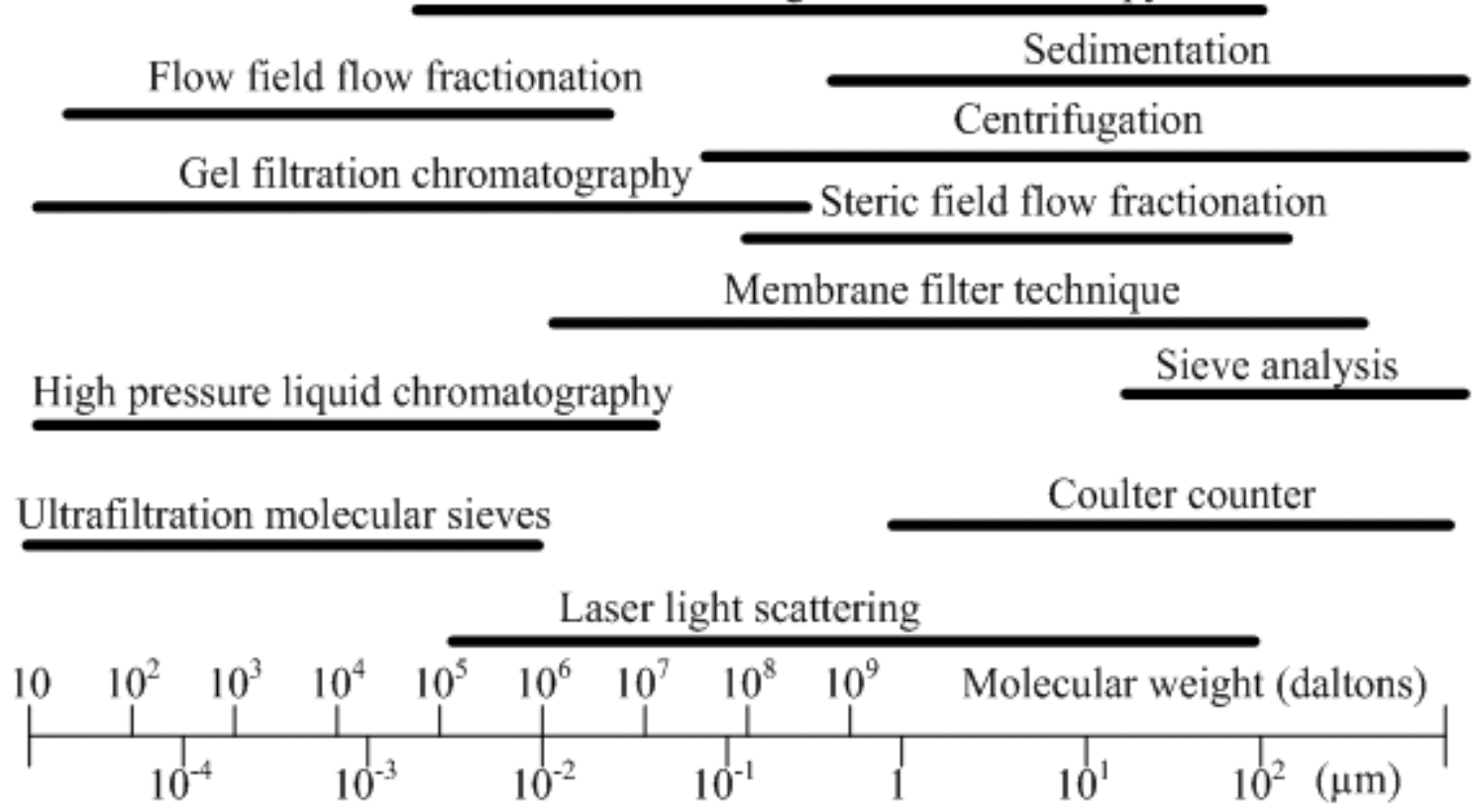

Figure 3 Analytical techniques used for identification of the size of wastewater contaminants smaller than $100 \mu \mathrm{m}$.

\section{Size Distribution of POC}

Size distribution of POC larger than $0.45 \mu \mathrm{m}$ can be characterized by sieving, membrane filtration, steric field flow fractionation (FFF), particle counting, scanning electron microscopy (SEM), and transmission electron microscopy (TEM). Direct microscopic analysis can be used as an alternative way when POC sizes exceed $500 \mu \mathrm{m}$. POC of this 
range generally includes algae, protozoa, bacteria, organic debris from food and human waste and floc and/or aggregate of OM. Membrane filtration and FFF are also used in size distribution analysis of DOC.

\section{Sieving and Membrane Filter Analysis}

Sieving and particulate membrane filter analysis are the oldest sizing methods. These both involve some kind of screens with uniform openings to separate different size fractions. Fractions of OM larger than screen openings are retained, and size distribution can be measured in terms of total organic carbon (TOC), biochemical oxygen demand (BOD), or chemical oxygen demand (COD).

Sieve analysis is usually used to measure the range of $5 \mu \mathrm{m}$ to $10 \mathrm{~cm}$. The standard methods of this technique can be found elsewhere (ISO, 1990; ASTM, 1995). To analyze smaller size OM of POC, often series of polycarbonate membrane filters used with pore sizes of $12,8,5,3,1$ and $0.45 \mu \mathrm{m}$. The advantages of these methods are easiness and affordability. The disadvantages of these techniques are that i) they are time consuming, ii) large sample volumes required and iii) smaller pore sizes can interfere with correct separation due to sieve and membrane fouling, termed as self-rejection, (ASTM, 1995).

\section{SEM and TEM}

Microscopic methods cover the size range of $0.001-200 \mu \mathrm{m}$. Based on the energy of involved electrons, and the way an electron collection, the methods are divided into TEM $(0.001-5 \mu \mathrm{m})$ and SEM $(0.02-200 \mu \mathrm{m})(\mathrm{Xu}, 2000)$. SEM probes the surface of particles which are first covered with a very thin layer of gold and then bombarded by electrons. TEM can show the internal structure of particles, therefore provides a more detailed characterization. Particle shapes and sizes can be deliberately measured using these techniques, however they are costly and time consuming (Levine et al., 1985).

\section{Steric FFF}


Separation in steric FFF is related to the physical properties of particle size, shape, density, and water viscosity in the $1-100 \mu \mathrm{m}$ range. The theory of steric FFF is based on different elution mechanisms of $\mathrm{OM}$ in terms of sizes. The procedure is utilizes the laminar flow which exists in the measuring channel and POC is separated by size in the flow streamlines, like in chromatography (Tong and Caldwell, 1995). Here, the diffusion of POC is negligible in retention. TOC and/or SEM can further analyze the separated POC. This technique is relatively new but well suited for POC size determinations.

\section{Particle counter with electronic pulse}

Particle counters using electronic pulses are widely used in laboratories. There are three instrumental counters, classified according to type of sensor involved: i) electrical sensing zone, ii) light blockage and iii) light scattering (Eaton et al., 1995). Size distribution of POC is measured by changes of the voltage, current, or resistance of electronic pulses.

When a particle moves through an orifice, it occupies some volume to causes a detectable change in an electrical field. The change of a current or resistance is proportional to the size of the particle. The measuring range starts from about $0.7 \mu \mathrm{m}$, and the maximum particle size is about $20 \%$ of an orifice diameter. The light blocking method consists of a measurement zone and a coupled photovoltaic cell. When POC passes through the sensor, the blockage of light produces voltage changes in the photovoltaic cell. With this method is possible to measure the range from $0.1 \mu \mathrm{m}$ to the employed orifice size. The light scattering method provides unique distribution patterns in terms of POC size. The measuring principle involves the shining of a laser (He-Ne) beam on POC. The diffraction light pattern is proportional to POC size, and correlated by the Fraunhofer or Mie theory. This theory concerns the refractive indices of the particles, of the dispersion media and the imaginary part of the refractive index of the particles. The range of the size measurement is from 0.02 to $2000 \mu \mathrm{m}$.

The disadvantages of these instruments are that i) gas bubbles and electronic noises cause interferences, ii) the sample should be diluted, and iii) color interference in methods which involve light. 


\section{Size Distribution of DOC}

In most waters DOC represent the dominant, larger part of OM. It is also recognized that a large amount of DOC is associated with vital or toxic chemicals. Aquatic humic substances contribute to over 50 percent of DOC in most natural waters, (Amy et al., 1987). Also, DOC is less easily removed than POC by liquid separation processes.

DOC smaller than $0.45 \mu \mathrm{m}$ can be separated by dialysis (Buffle et al., 1992), laser desorption Fourier transform mass spectrometry (LDFTMS) (Novotny et al., 1995), vapor pressure osmometry (VPO) (Aiken and Malcolm, 1987), ultracentrifugation (Reid et al., 1990), X-ray scattering (Thurman et al., 1982), ultrafiltration (UF) technique (Cai, 1999), flow FFF (Beckett et al., 1987), gel permeation chromatography (GPC) (Levine, 1985) and HPSEC (Zhou et al., 2000).

Table 2 summarizes main characteristics of these analytical methods. Separation of DOC by dialysis is simple, with the main force being diffusion. However, it is also a time consuming process, and the need for large sample volumes limit the application of this technique. LDFTMS, VPO and ultracentrifugation are rarely applied to size distribution determinations in water. In contrast, UF, HPSEC and flow FFF are widely employed thus we focus on these methods. 
Table 2 Characteristics of methods used for the determination of DOC size distribution (adapted from Thurman et al., 1982; Levine, 1985; Aiken and Malcolm, 1987; Beckett et al., 1987; Reid et al., 1990; Buffle et al., 1992; Novotny et al., 1995; Cai, 1999; Zhou et al., 2000; Kim and Koo, 2002).

\begin{tabular}{|c|c|c|}
\hline Technical method & Advantage & Disadvantage \\
\hline Dialysis & $\begin{array}{l}\text { - Simple application } \\
\text { - Natural force (diffusion) }\end{array}$ & $\begin{array}{l}\text { - Time consuming } \\
\text { - Large sample volume required } \\
\text { - Limited range of size } \\
\text { distribution }(2-5 \mathrm{~nm}) \\
\text { - Careful handling of membrane }\end{array}$ \\
\hline LDFTMS & $\begin{array}{l}\text { - Independent on the material } \\
\text { being characterized } \\
\text { - Relatively accurate size }\end{array}$ & $\begin{array}{l}\text { - High power required } \\
\text { - Concentrated samples required } \\
\text { - Small MW measured }\end{array}$ \\
\hline VPO & & $\begin{array}{l}\text { - Limited range of size } \\
\text { distribution } \\
\text { - Yield only a number-average } \\
\text { MW } \\
\text { - Corrections for ionizable } \\
\text { compounds }\end{array}$ \\
\hline Ultracentrifugation & $\begin{array}{l}\text { - Various molar mass }\left(\mathrm{M}_{\mathrm{w}}, \mathrm{M}_{\mathrm{n}} \text {, }\right. \\
\left.\text { and } \mathrm{M}_{\mathrm{z}}\right)\end{array}$ & $\begin{array}{l}\text { - Diffusion coefficient required } \\
\text { - Swamping of charge effects; } \\
\text { absorptivity varies with MW }\end{array}$ \\
\hline UF & $\begin{array}{l}\text { - Relatively inexpensive } \\
\text { - nondestructive and regent-free } \\
\text { - Simple application } \\
\text { - High reliability }\end{array}$ & $\begin{array}{l}\text { - Effect of self rejection } \\
\text { - Broad range of size distribution } \\
\text { - Large sample volume required } \\
\text { - Influence of ionic strength, pH } \\
\text { and concentration polarization } \\
\text { - Difficult separation with high } \\
\text { concentration }\end{array}$ \\
\hline Flow FFF & $\begin{array}{l}\text { - Identification of interaction } \\
\text { between membrane and OM }\end{array}$ & - Sorption on the membrane \\
\hline HPSEC & $\begin{array}{l}\text { - Small sample volume required } \\
\text { - Specific range of size } \\
\text { distribution } \\
\text { - Automatic analysis } \\
\text { - A number of compatibilities } \\
\text { - Relatively inexpensive }\end{array}$ & $\begin{array}{l}\text { - Errors due to chemical } \\
\text { interactions among OM, column } \\
\text { packing and eluent } \\
\text { - Electrostatic interaction } \\
\text { - Sorption } \\
\text { - Calibration required } \\
\text { - Specific analysis depending on } \\
\text { detectors used } \\
\text { - Effect of pH }\end{array}$ \\
\hline
\end{tabular}

\section{Ultrafiltration}


The UF technique is affordable thus widely used to separate species by molecular size, shape and charge. This method covers the range of MW distribution from less than 1,000 to more than 100,000 Da. UF involves the selective rejection of solutes by convective flow through a membrane. The targeted MW can be selected in terms of MWCO of membranes. Solutes of larger than the specified MWCO are quantitatively retained, while solutes of smaller MW pass the membrane in the permeate.

The main phenomena involved in UF separation are advective flow and molecular diffusion. The solute flux is related to the area of membrane, concentration gradient and diffusion. Stevenson E.J. (1982) observed that the extent of interactions between OM and UF depended on concentration, ionic composition, presence of polyvalent cations and $\mathrm{pH}$. Cai (1999) also reported that retention or rejection of solute was a function of MW size and shape, also influenced by a number of factors, such as solute concentration, ionic strength, concentration polarization and $\mathrm{pH}$. Macko et al. (1979) suggested that $\mathrm{pH}$ and ionic strength should be held constant for uniform results. By contrast, Brock (1983) reported that varying $\mathrm{pH}$, electrolyte concentration and pressure did not change the results, but $\mathrm{OM}$ concentration affected the solute retention. Increasing the OM concentration decreased the solute retention (Ogura, 1974). Buffle et al. (1978) reported that an increase in the initial OM concentration resulted in an increase in the retention of large MW, but a decrease in the retention of small MW. Macko et al. (1979) investigated ways to reduce concentration polarization, and found that vigorous mixing and dilution of the feed solution were advantageous. Brock (1983) suggested that the phenomena of Donnan effect might lead to an unequal distribution of ions so that proteins may be unable to pass the membrane.

In general, this method is reproducible and accurate. Reproducibility can be maintained with proper cleaning, and accuracy can be improved by using larger sample volumes.

\section{HPSEC}

Since 1958 HPSEC, also known as gel permeation chromatography (GPC), and gel filtration chromatography (GFC), has been one of the most commonly used methods to determine size distribution of DOC. It is a versatile method having a relative ease of 
application, modest equipment requirements and ability to generate both average and distributed size information (Poole, 2003). The origin of modern HPSEC can be traced to the introduction of crosslinked poly(dextran) and poly(saccharide) gels used for the size separation of water-soluble biopolymers and of semi-rigid, porous crosslinked poly(styrene) gels for the separation of organic polymers. These developments occurred in parallel with the separation of water-soluble biopolymers (GFC), mainly a concern of biochemists, and the separation of organic polymers (GPC) by polymer chemists. The division is redundant today, and size-exclusion chromatography is the preferred term for all separations resulting from the size-dependent distribution of sample molecules between a mobile phase and a porous stationary phase (Poole, 2003).

Solute separation in terms of MW distribution is based on the different abilities of the various solutes to enter the pores of the stationary phase via molecular diffusion. Solute of large MW cannot enter the stationary phase and moves quickly through the void volume of the bed, whereas solute of small MW can enter the gel pores, thus its movement through the column is retarded (Amy et al., 1987b).

Column materials for use in HPSEC are rigid and include carbohydrates, methacrylates, silicas and polystyrene. Silica, zirconium-stabilized silica, and controlled pore glass are extremely rigid materials that can withstand the relatively high pressures used in high performance liquid chromatography (HPLC). Carbohydrates and some polystyrenes are considered to be microporous, while silicas and some polystyrenes are regarded macroporous. Many researchers (Kainulainen et al., 1994; Shaw et al., 1994; Cho, 1998; Pelekani et al., 1999; Her, 2002; Shon et al., 2005) used various silica-based gels in order to characterize water and wastewater samples. These include Sephadex, Waters ProteinPak 125 and TSK gel. Chin et al. (1994) and Shon et al. (2004) also used a modified silica column (Protein-Pak 125, Waters Co.) to analyze MW distribution of DOC and weightaveraged MW values.

Standard solutions of different polystyrene sulfonates with known MW (PSS: 210, 1,800, 4,600, 8,000, and 18,000 Da) are typically used to calibrate the HPSEC equipment (Her et al, 2002). The MW distribution is represented by an UV response (mV intensity) with time. 
Results can also be presented as normalized fraction percentages, obtained by dividing each incremental height of the chromatogram with a sum of the heights when the chromatogram was divided into incremental mass intervals (Cho et al., 2000; Lee et al., 2002).

The statistics of MW distribution by HPSEC have been well defined (Table 3). There are four average values of $M W$ : i) $M_{n}$ (number average $M W$ ), ii) $M_{w}$ (weight average $M W$ ), iii) $M_{z}$ (z-average molecular weight) and iv) $M_{v}$ (viscosity average $M W$ ). Among these statistics of MW distribution, the weight average MW $\left(\mathrm{M}_{\mathrm{w}}\right)$ is commonly used. The number average MW $\left(M_{n}\right)$ is obtained by multiplying the number of chains of a certain length with their MW and adding this to the number of a second class of chain multiplied by their MW, and so on, then dividing by the total number of chains (Mulder, 1996). The use of weight fraction $\left(\mathrm{N}_{\mathrm{i}} \mathrm{M}_{\mathrm{i}}\right)$ instead of the number of $\mathrm{MW}\left(\mathrm{N}_{\mathrm{i}}\right)$ results in the weight average MW $\left(\mathrm{M}_{\mathrm{w}}\right)$. A distribution can be expressed in terms of the polydispersity $\left(\mathrm{P}=\mathrm{M}_{\mathrm{w}} / \mathrm{M}_{\mathrm{n}}\right)$.

Table 3 Molecular weight statistics.

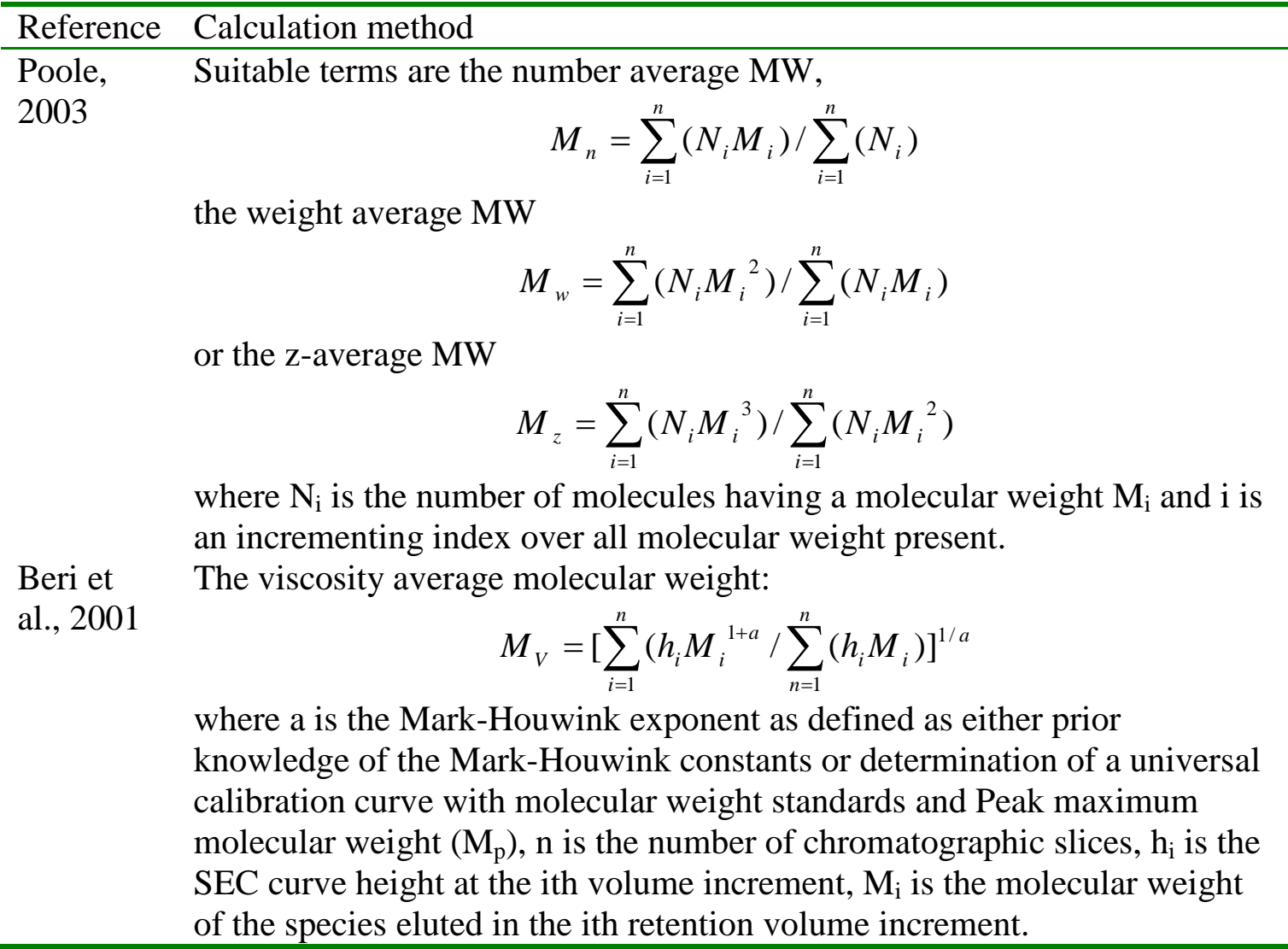


HPSEC separation is dependent on i) the degree and method of concentration of OM, ii) the type and grade of the gel, iii) the standard biochemicals or synthetic chemicals used to calibrate the column, and iv) the composition of the eluent. Cai (1999) suggested that significant errors might occur due to chemical interactions among the column packing, the eluent and the organic components. Further, the extent of interaction may be influenced by the degree of DOC concentration, the presence of polyvalent cations and the ionic strength (Amy et al., 1987b). Amy et al. (1987b) also reported that this method was more profoundly affected by $\mathrm{pH}$, suggesting that the UF method rather than HPSEC technique may be more appropriate when $\mathrm{pH}$ conditions are important. While comparing the MW distribution of DOC in raw waters and drinking waters, Nissinen et al. (2001) found that the HPSEC method was sensitive to different water sources.

Gjessing and Lee (1967) reported that the shapes and sizes of the small MW components could determine the extent of their penetration into the gel beads, leading to an underestimation of low MW components. Thurman and Malcolm (1979) observed that negatively charged MW traveled faster than non-charged DOC of similar size through the gel column. Increased $\mathrm{pH}$ increased the solubility of humic molecules as a result of ionization of functional groups, and reduced hydrogen bonding with the resin. Swift and Posner (1971) observed that adsorption between gel and DOC strongly correlated with the degree of gel cross-linking. Cameron et al. (1972) found that the behavior of humic acids on gels could not be predicted from the calibration curves obtained for proteins or dextrans.

MW distribution was rigorously related to hydrodynamic sizes of the OM rather than to MW (Stevenson, 1982). Amy et al. (1987b) suggested that it is important to maintain the same experimental conditions in analyzing different water sources. Zhou et al. (2000) observed that this method did not always provide reproducible results for humic substances, sowing $10 \%$ - $20 \%$ variability. While the method of baseline correction of large MW cutoff of the HPSEC chromatogram was not important, the choice of small MW cutoff could greatly affect $M_{n}$ and P. Although the PSS standards are commonly used in combination with acetone, they suggested the inclusion of salicylic acid as a charged small MW standard. Also, they recommended UV detection wavelengths between 230 and 
$280 \mathrm{~nm}$ for reasonable results, noting that higher wavelengths could bias larger MW matter. In general, $254 \mathrm{~nm}$ wavelength is suitable, except for samples of low carbon concentration where $230 \mathrm{~nm}$ provides better sensitivity. As such, they resulted in excellent reproducibility (2 - 3\%) of $\mathrm{M}_{\mathrm{n}}$ and $\mathrm{M}_{\mathrm{w}}$.

Figure 4 shows a typical chromatogram for MW distribution of DOC. The MW of EfOM in BTSE ranged from 260 to about 43,110 Das, with the highest fraction being 263 to 870 Da. The compound of 43110 Da may be polysaccharide; 580 Da and 865 - humic substances; $330 \mathrm{Da}$ - building blocks; $250 \mathrm{Da}$ - acids, and less than $200 \mathrm{Da}$ - amphiphilics (Huber, 1998).

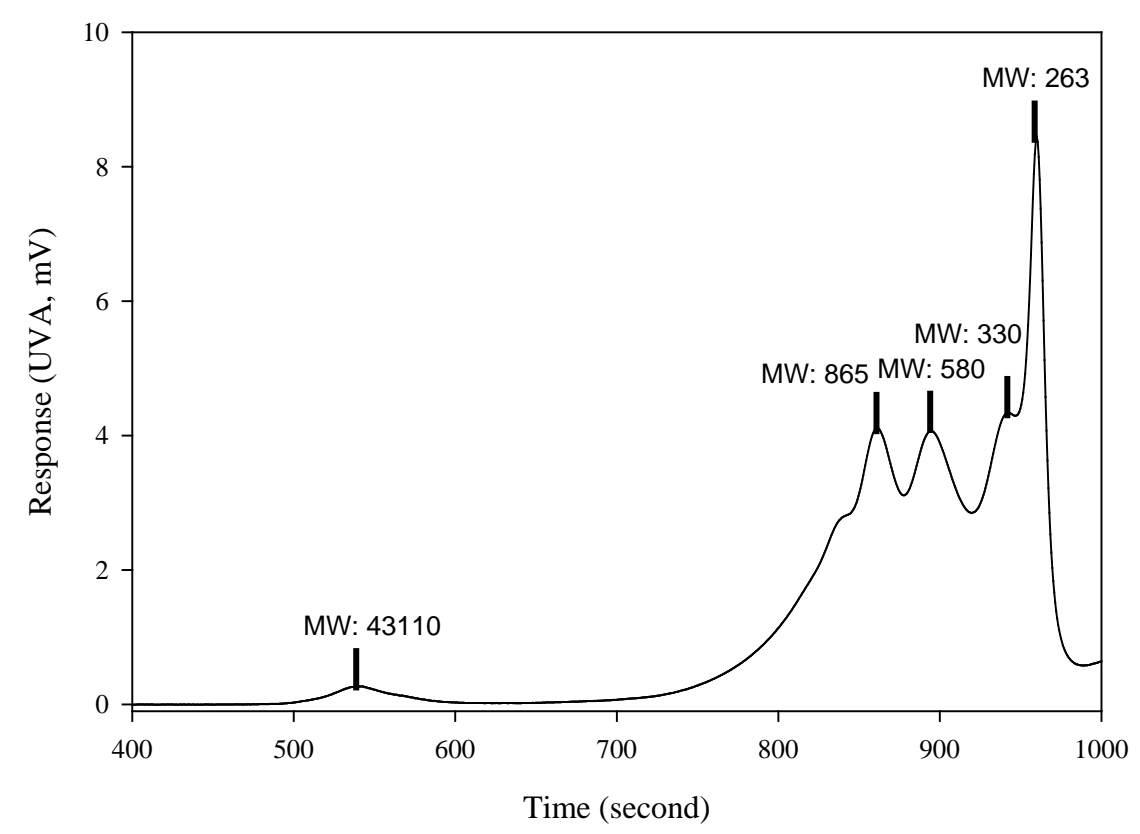

Figure 4 MW distribution of EfOM in BTSE by HPSEC technique.

\section{Coupling of UV and Fluorescence Detectors}

Since UV at $254 \mathrm{~nm}$ is preferentially absorbed by $\pi$-bonded molecules of organic matter, HPSEC with the UV detector is chiefly applied to MW estimations of humic and fulvic acids, and the aromatic hydrophobic portion of DOC. This has the limitation of detecting low UV-absorbing components, such as proteins and polysaccharides. Thus, fluorescence detectors are often employed to interpret protein-like substances. Fluorescence detectors are used at two wavelengths, excitation (279 nm) and emission (353 nm) (Her, 2002). 
Leenheer and Croue (2003) classified more detailed major fluorescent component in excitation and emission in terms of different organic types. The analysis set-up of the assembly is presented in Figure 5. The calibration of the equipment is generally conducted with the same standards (PSS).

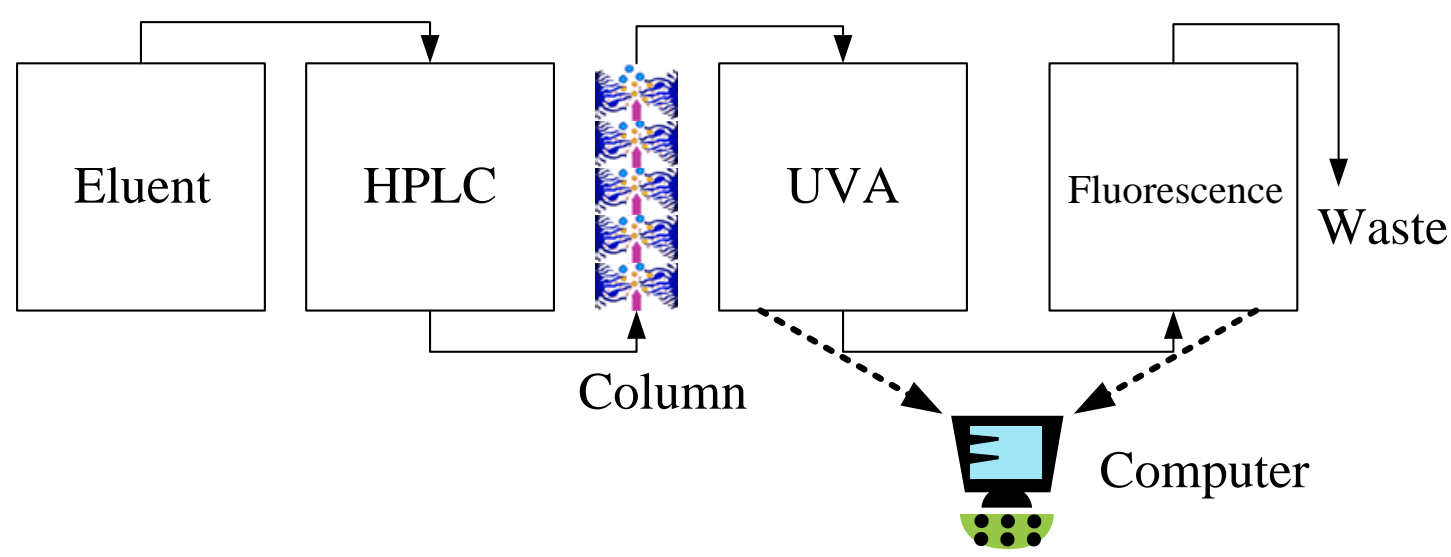

Figure 5 Schematic diagram of HPSEC coupled with UV-fluorescence detector.

Figure 6 (a) shows a sample by the fluorescence chromatogram at $279 \mathrm{~nm}$ excitation and $353 \mathrm{~nm}$ emission. For comparison, the MW distribution by the $254 \mathrm{~nm}$ UV detector is also shown in Figure 6 (b). Figure 6 (a) detects the high responses at 44,944 and 235 Da, which could be protein-like substances. However, the MWs of 376 and 748 Da have low intensity, suggesting that these peaks may be due to humic substances (humic and fulvic acids). 


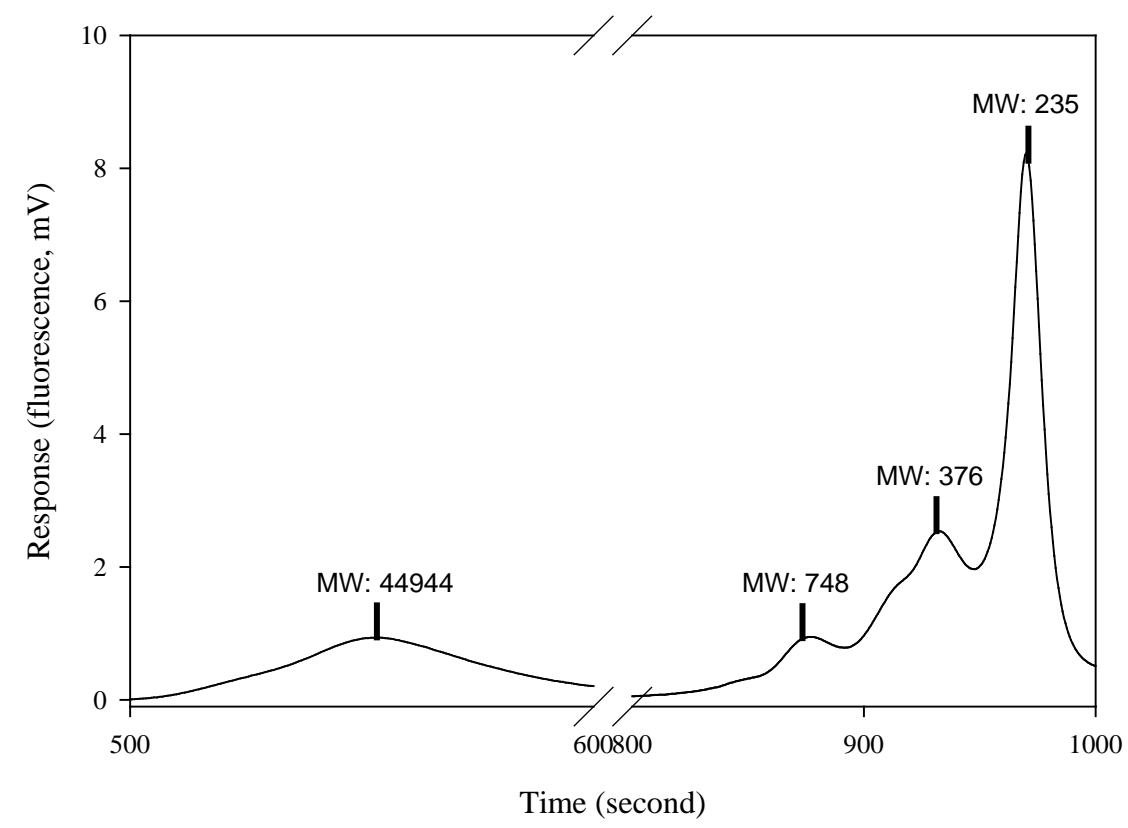

a)

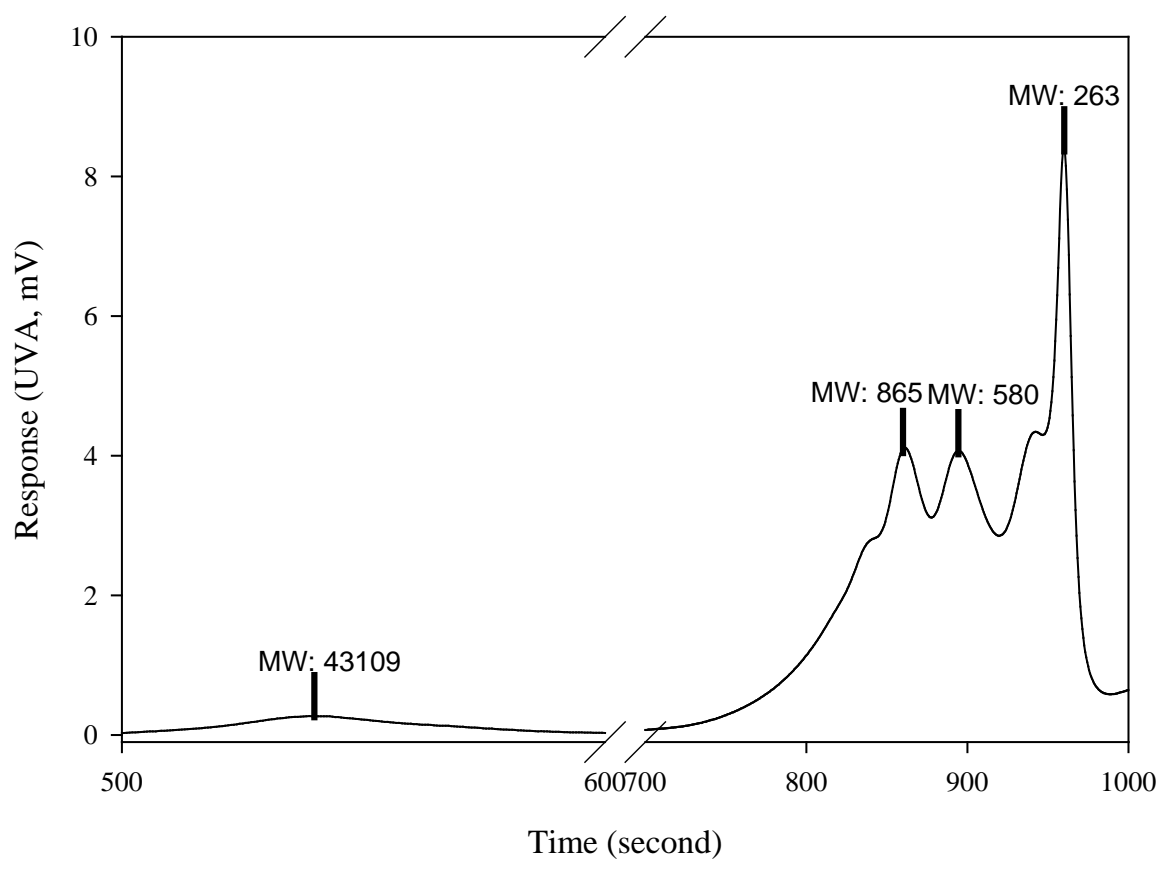

b)

Figure 6 Comparison of (a) fluorescence chromatogram and (b) UV chromatogram for MW distribution of EfOM with BTSE (initial DOC concentration = $6.5 \mathrm{mg} / \mathrm{L}$ ).

\section{Coupling of UV and DOC detectors}


HPSEC technique coupled with UV-DOC detector to provide qualitative information (e.g., a specific UVA (SUVA) chromatogram as a function of MW by the relative ratio between UVA at $254 \mathrm{~nm}$ and DOC) in addition to quantitative information on MW distribution. With an on-line DOC detector, all organic compounds can be recognized and the SUVA values can be monitored in real-time (Figures 7 and 8). As can be seen in Figure 7, the UV and the DOC chromatograms gave completely different results. The UV detector showed higher response at $900 \mathrm{Da}$ than at 13,500 Da, while the DOC detector showed an opposite pattern. This indicates that the compound of $900 \mathrm{Da}$ could be more aromatic or hydrophobic than the compound of $13,500 \mathrm{Da}$. Nonetheless, this system is not sufficient to identify chemical and physical properties of a particular DOC compound. The combination (HPSEC-UVA-Fluorescence-DOC) helps to discriminate DOC components such as specific biopolymer, aromaticity and DOC fraction. Huber (1998b) reported that this approach was successfully applied to other fields of water analysis, like highly mineralized table waters, marine waters, wastewaters and soil extracts.

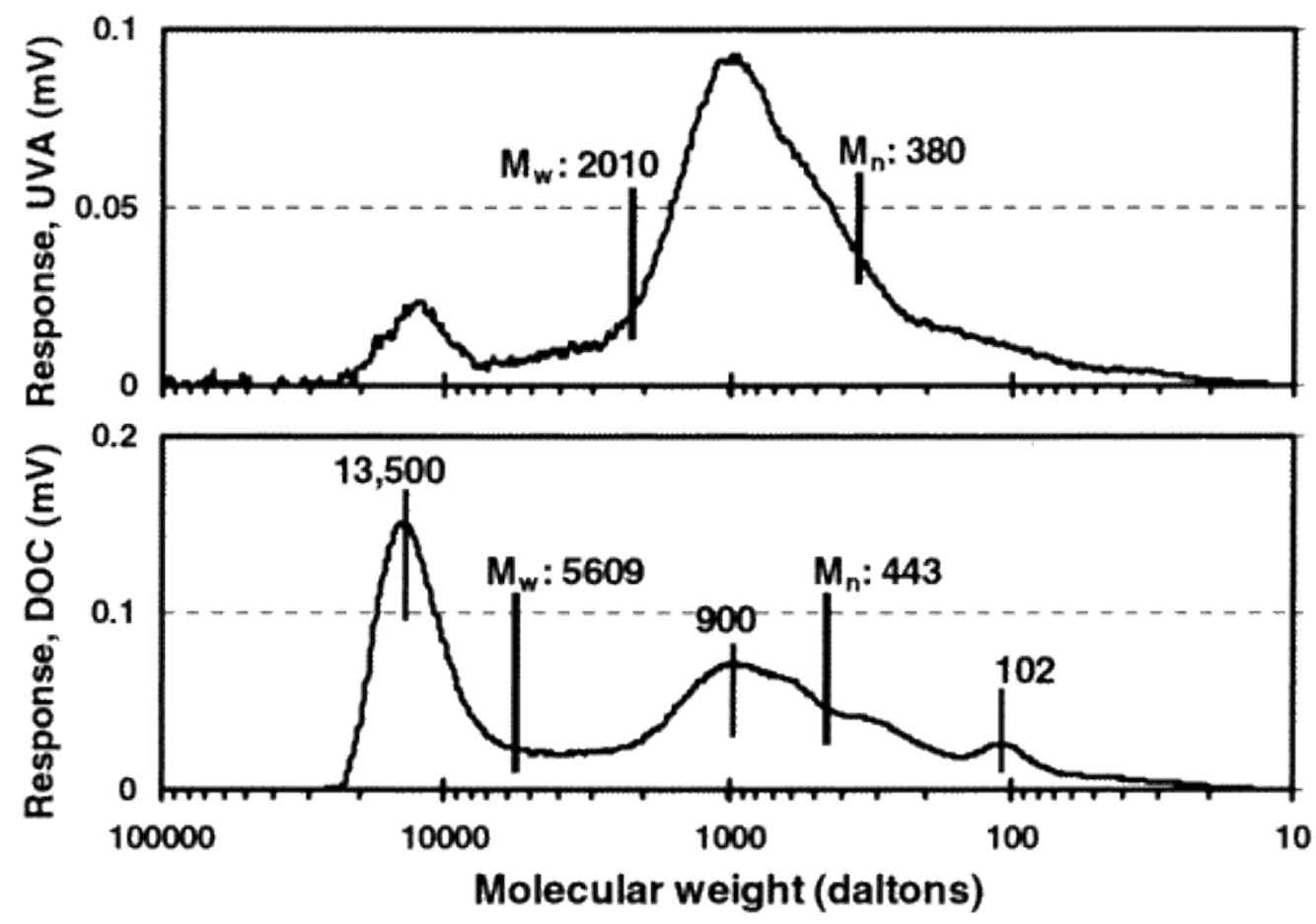

Figure 7 HPSEC-UV-DOC chromatograms for Barr Lake in USA (adapted from Her et al., 2002). 


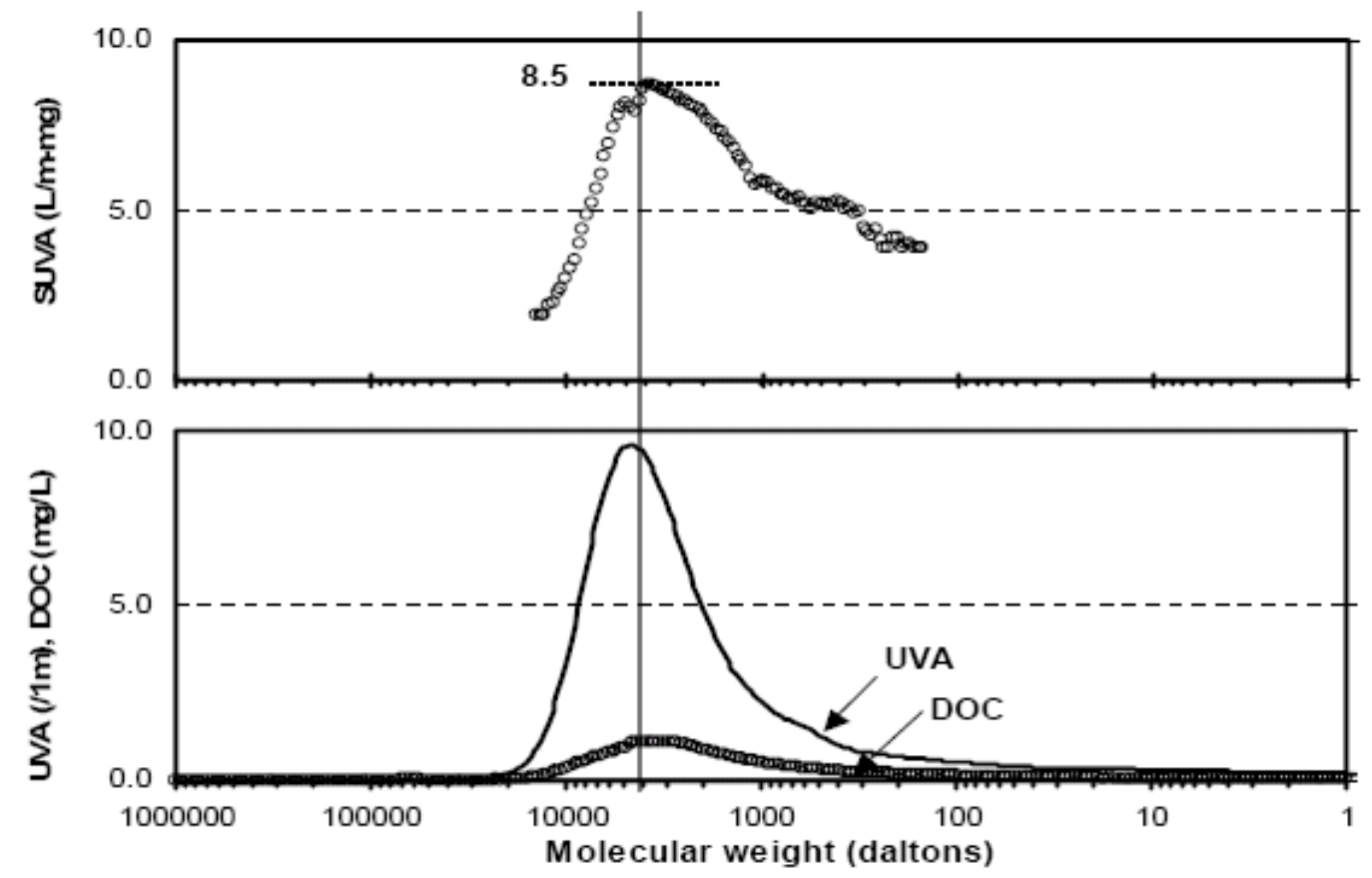

Figure 8 SUVA values by HPSEC-UVA-DOC (adapted from Her, 2002).

\section{UV Absorbance Ratio Index (URI)}

URI is the ratio of UV absorbances at $210 \mathrm{~nm}$ and $254 \mathrm{~nm}\left(\mathrm{UVA}_{210} / \mathrm{UVA}_{254}\right)$ which provides qualitative information on the relative proportion between UV-absorbing functional groups and unsaturated compounds. On the one hand, unsaturated compounds effectively absorb UV light at both 254 and $210 \mathrm{~nm}$ wavelengths (Figure 9). On the other hand, functional (amino) groups absorb UV light more effectively at 210 than at $254 \mathrm{~nm}$. Therefore, a higher density of functional (e.g., amino) groups result in a higher absorption at $210 \mathrm{~nm}$, and subsequently produces a higher URI. Her (2002) found that proteins and amino acids have higher URI than humic substances. The URI values are the lowest for humic acids with the highest aromaticity (1.59), medium for fulvic acids with intermediate aromaticity (1.88), and the highest for proteins of bovine serum albumin with lowest aromaticity (13.50). Therefore, the URI analysis effectively distinguishes protein-like substances from other DOC components. Figure 9 presents HPSEC-UV chromatograms (at 210 and $254 \mathrm{~nm}$ ) and URI values (UVA $210 / \mathrm{UVA}_{254}$ ) for humic acids. A URI value at 3,400 Da indicates the presence of high density of UV absorbing functional groups. The URI value of 1.6 implies the lowest proportions of functional groups with the highest proportions of aromatic rings, which could be humic acids. 

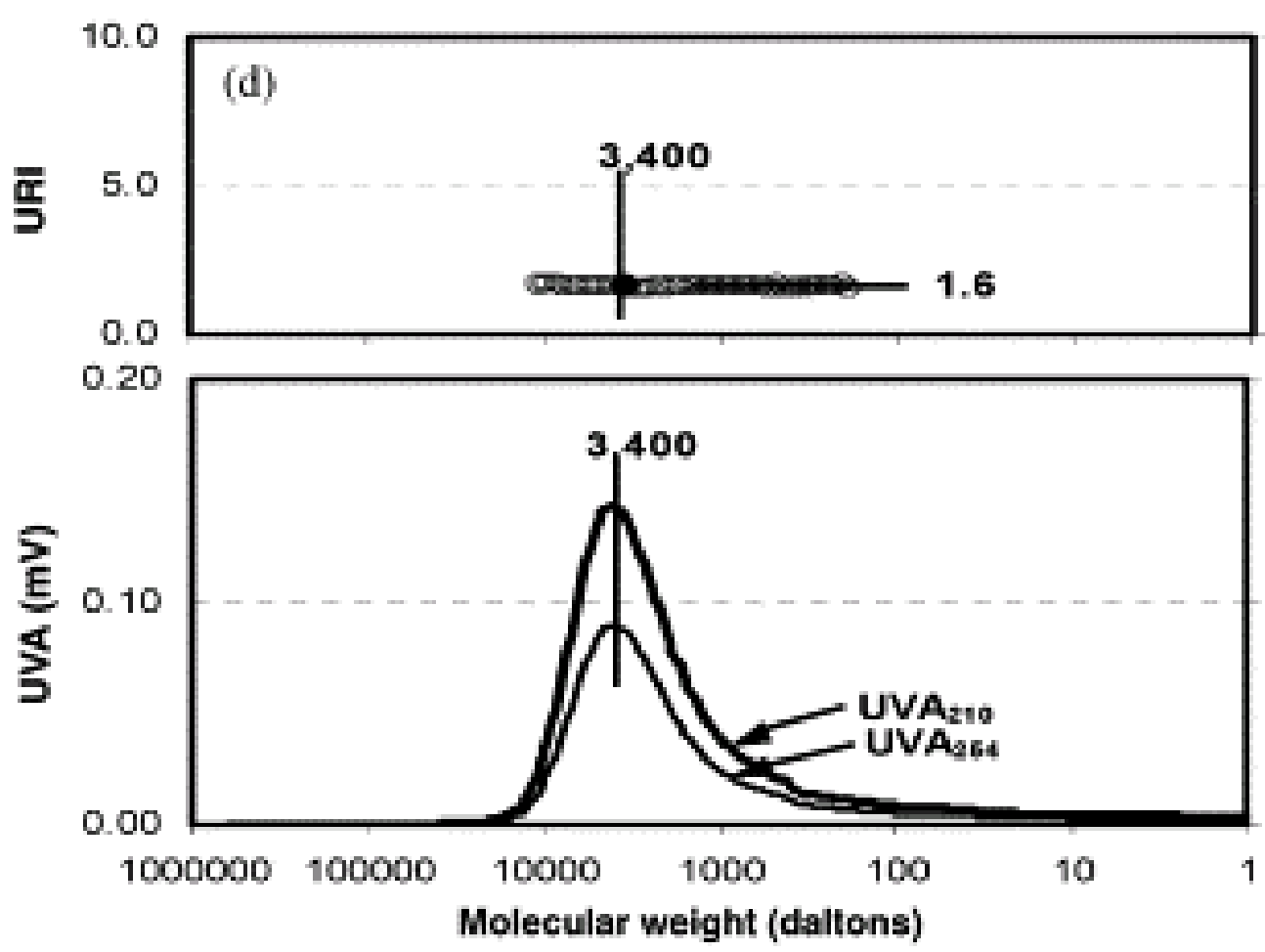

Figure 9 URI and HPSEC-UV chromatograms for humic acid (adapted from Her, 2002).

\section{Flow FFF}

Flow FFF is a fractionation method based on a channel with walls consisting of a ceramic frit material. It has been traditionally developed to determine MW distribution, diffusivity and hydrodynamic sizes of DOC. The method does not require chromatography packing material. Steric FFF to measure POC sizes by collecting samples with retention time, while flow FFF measures DOC with combined UV absorbance and fluorescence detectors, in real-time.

There are two liquid flows in the flow FFF method: i) channel flow and ii) second crossflow at $90^{\circ}$ to the channel (Figure 10). A semi-permeable membrane is placed on one side of the channel, allowing the cross-flow to pass but not the compounds of interest. Flow FFF separates DOC according to molecular sizes. Diffusion coefficients are calculated from the retention time and channel operating conditions. With appropriate standards such as PSS, MW distributions are determined (Zanardi-Lamardo et al., 2002). A major 
advantage of this technique is the identification of the interactions between a semipermeable membrane and DOC (Hartmann and Williams, 2002).

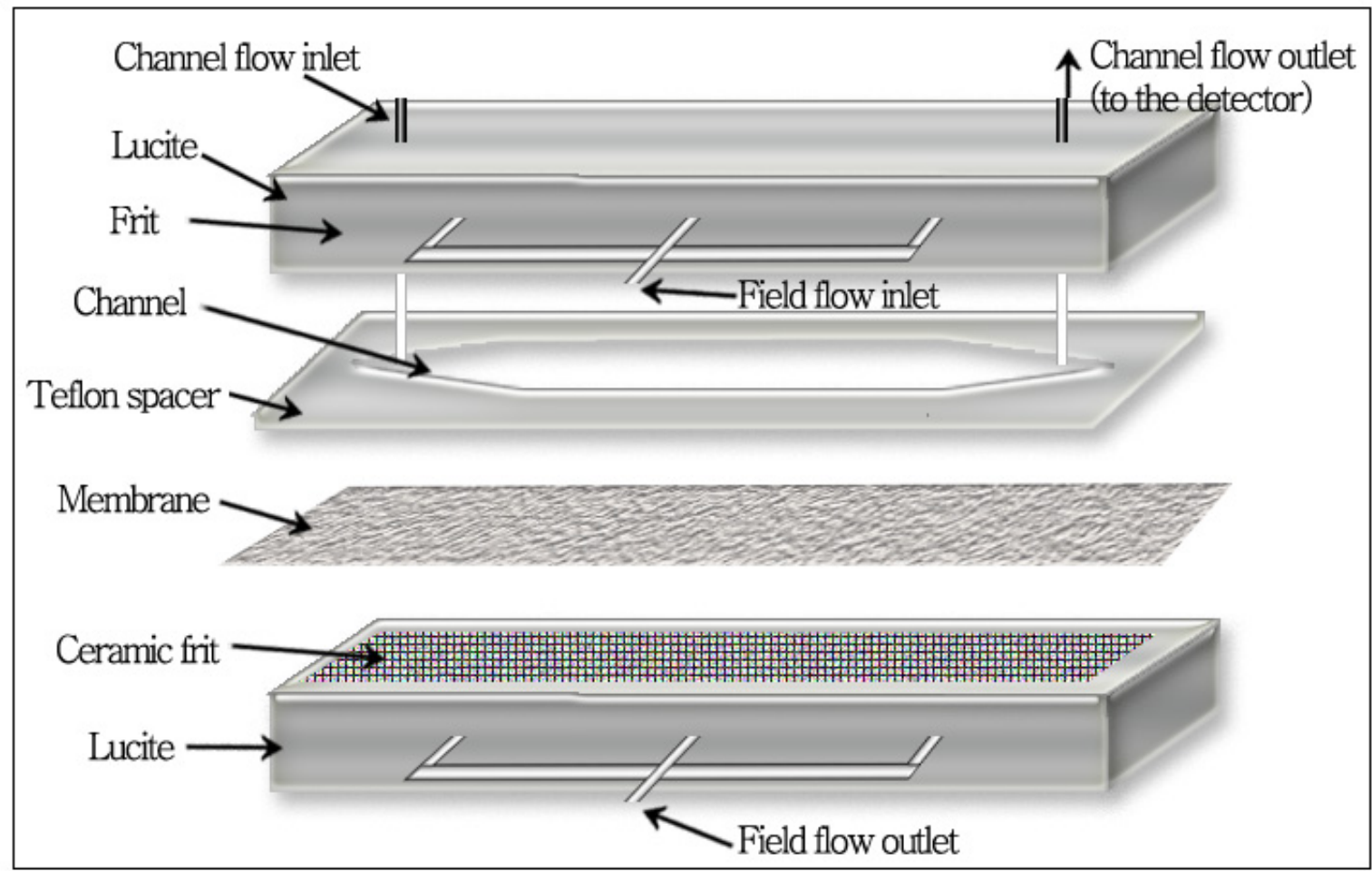

Figure 10 Schematic diagram of a flow FFF channel

The flow FFF can be applied to environmental and biological matrices and to the detection of polymers and inorganic colloids (Gimbert et al., 2003). Various detectors can be coupled, depending on the targeted DOC. In general, UV absorbance by DOC is monitored at $254 \mathrm{~nm}$, and fluorescence is measured at excitation and emission wavelengths of 228 and $360 \mathrm{~nm}$, respectively. Both the retention time and the peak area are obtained. This method covers the size range from about 500 Da to $1 \mu \mathrm{m}$. The precisions for both detectors, after a flow FFF run, are from 1.4 - $2.5 \%$, based on the variation of the retention time, and 3.3 - 3.9\%, based on the peak areas (Zanardi-Lamardo et al., 2001). A method of characterizing DOC by asymmetrical flow field-flow fractionation with on-line UV and DOC detection is described and applied to standards and natural water samples (Reszat and Hendry, 2005). MW determinations in the samples and standards were 6-30\% lower with DOC analysis than with UV analysis. This difference was due to the insensitivity of the latter technique to non-aromatic carbon, suggesting that MW determined with the DOC 
detector is a more accurate representation of the actual MW of DOC. A normalized intensity comparison method was applied to yield an average aromatic content of the bulk DOC and to detail the aromatic content over a range of MW.

Table 4 summarizes the application of flow FFF to environment matrices. In this method regenerated cellulose membrane are used most often, with UV detection is the range of 254 $\mathrm{nm}$ to $330 \mathrm{~nm}$. Figure 11 shows relative molecular weight (RMM) distributions of surface water samples by fluorescence and UV detectors. The representative chromatogram of flow FFF is similar with that of HPSEC.

Table 4 Environmental applications (adapted from Gimbert et al., 2003).

\begin{tabular}{|c|c|c|c|c|}
\hline Analyte & Crossflow & Membrane & Carrier liquid & Detector \\
\hline $\begin{array}{l}\text { Colloids (in coastal } \\
\text { seawater) }\end{array}$ & Recirculating & $\begin{array}{l}\text { Regenerated cellulose, } \\
\text { 10,000 Da nominal } \\
\text { MWCO }\end{array}$ & $\begin{array}{l}\text { Seawater with } \\
\text { addition of } \\
\text { biological non-ionic } \\
\text { surfactant } \\
\text { (Pluronic F68) to final } \\
\text { concentration of } 0.1 \% \\
\text { (v/v) }\end{array}$ & UV (254 nm) \\
\hline $\begin{array}{l}\text { Dissolved organic } \\
\text { material } \\
\text { (colored, in river } \\
\text { and coastal waters) }\end{array}$ & Recirculating & $\begin{array}{l}\text { Regenerated cellulose, } \\
3000 \text { Da } \\
\text { nominal MWCO for } \\
\text { globular } \\
\text { compounds } \\
\text { (FFFractionation) }\end{array}$ & $\begin{array}{l}0.005 \% \text { FL-70, } 0.05 \\
\mathrm{M} \text { Trisma and } \\
0.029 \mathrm{M} \mathrm{HCl} \\
\text { prepared in organic- } \\
\text { free distilled water, to } \\
\text { give pH } 8 \text { and ionic } \\
\text { strength of } 0.08 \mathrm{M}\end{array}$ & $\begin{array}{l}\text { UV (330 nm) and } \\
\text { fluorescence }\end{array}$ \\
\hline $\begin{array}{l}\text { Dissolved organic } \\
\text { carbon } \\
\text { (in fresh and } \\
\text { marine waters) }\end{array}$ & $\begin{array}{l}\text { Non- } \\
\text { recirculating }\end{array}$ & $\begin{array}{l}\text { Modified polyether sulfone } \\
\text { Membrane } \\
\text { (Omega), } 1000 \text { MWCO } \\
\text { optimum }\end{array}$ & $\begin{array}{l}\text { (i) } 25 \text { mM Tris, } 20 \\
\text { mM sodium } \\
\text { chloride (ii) } 10 \mathrm{mM} \\
\text { borate, } 20 \mathrm{mM} \\
\text { sodium chloride - } \\
\text { optimal carriers }\end{array}$ & UV (270 nm) \\
\hline $\begin{array}{l}\text { Dissolved organic } \\
\text { matter } \\
\text { (pulp and paper } \\
\text { mill effluents) }\end{array}$ & $\begin{array}{l}\text { Non- } \\
\text { recirculating }\end{array}$ & $\begin{array}{l}\text { Cellulose acetate, } \\
\text { (manufactured in } \\
\text { laboratory) }\end{array}$ & $\begin{array}{l}\text { Distilled deionised } \\
\text { water with } 0.05 \mathrm{M} \\
\text { tris buffer adjusted to } \\
\text { pH } 8.0 \text { by addition of } \\
\mathrm{HCl} \text {. Ionic strength } \\
\sim 0.03 \mathrm{M}\end{array}$ & UV (254 nm) \\
\hline $\begin{array}{l}\text { Dissolved organic } \\
\text { matter } \\
\text { in seawater) }\end{array}$ & Recirculating & $\begin{array}{l}\text { Regenerated cellulose } \\
\text { (YM-10, Amicon), 10,000 } \\
\text { Da nominal MWCO }\end{array}$ & UV-oxidised seawater & $\begin{array}{l}\text { UV and } \\
\text { fluorescence }\end{array}$ \\
\hline
\end{tabular}




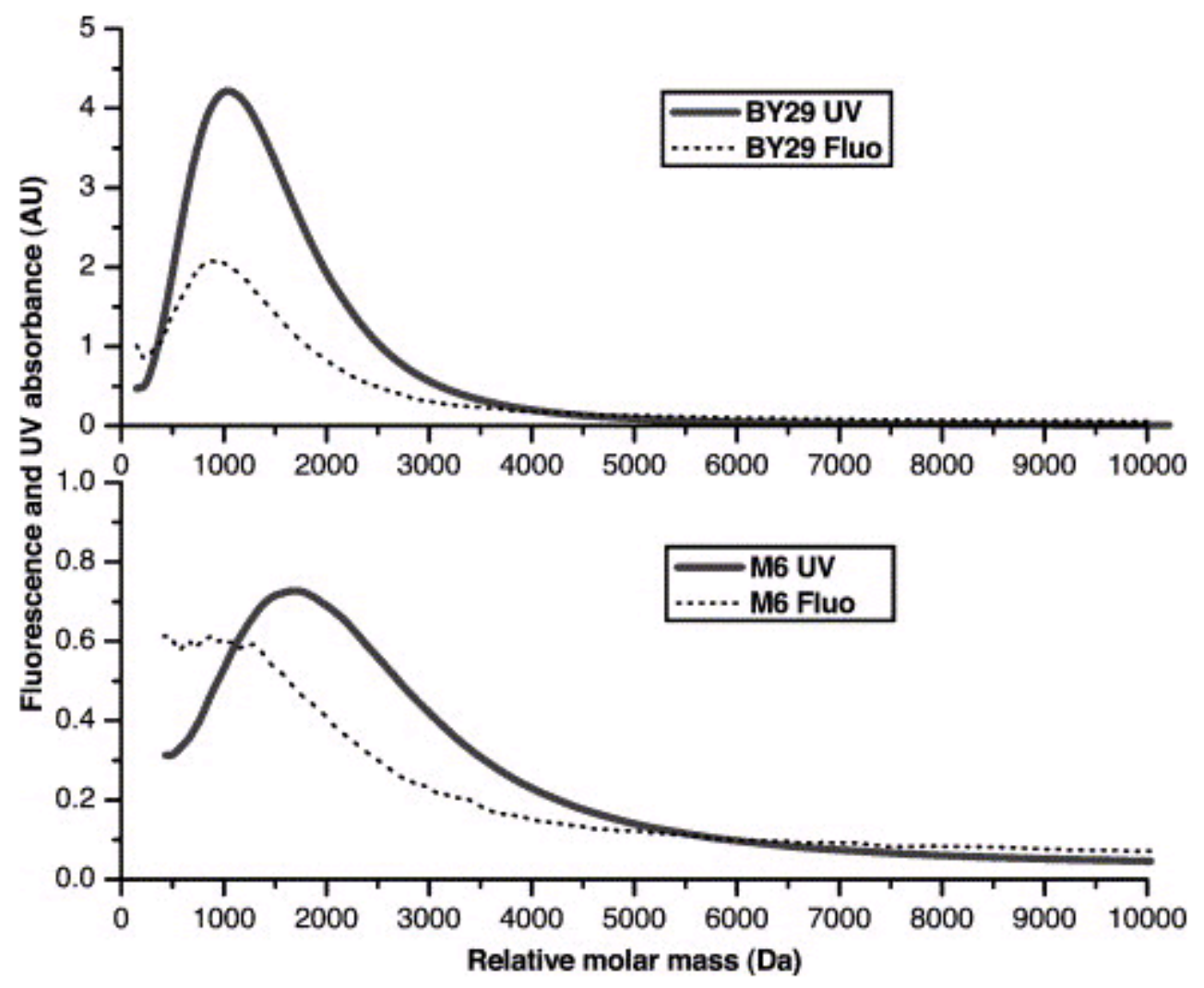

Figure 11 Relative molar mass distributions of fluorescence and UV absorbance from two contrasting surface water samples from station marine (M6) and brackish (BY29) (adapted from Hassellöv, 2005).

The coupling of flow FFF with other detectors, such as flow injection-spectrophotometry incorporating selective derivatisation reactions and inductively coupled plasma mass spectrometry (ICP-MASS), will produce novel multi-dimensional information (Gimbert et al., 2003).

\section{Concluding Remarks}

Size distribution is an important analytical tool to characterize OM. For size distribution of POC (above $0.45 \mu \mathrm{m}$ ), sieving, membrane filtration technique, steric FFF, particle counting with electronic pulse, SEM and TEM are available. Light scattering techniques, such as particle counting are replacing the conventional methods of sieving and membrane filter technique for size distribution of POC. 
Size distribution of DOC has drawn more attention than that of POC. This is partly because DOC imparts many adverse effects to water, and partly because solid-liquid separation processes more easily remove POC. For size distribution determinations of DOC the available methods include dialysis, LDFTMS, VPO, ultracentrifugation, X-ray scattering, ultrafiltration, flow FFF, GPC, and HPSEC. The conventional methods of ultrafiltration and GPC have gradually been replaced by flow FFF and HPSEC with coupled detectors. The use of HPSEC is widespread due to several reasons, including small sample volumes, specific range of size distribution, automatized analysis, and relatively small costs. Still, HPSEC has limitations, and have been improved by coupling it with other analytical methods, such as fluorescence and UV absorbance ratio index (URI), resulting in better reproducibility. A more deliberate classification of $\mathrm{OM}$ with real time was also possible. However, chemical interactions among OM, column packing, and eluent should be carefully considered. Although HPSEC characterizes size distribution of most OMs, it cannot detect emerging compounds such as POPs, EDCs, and PPCPs.

Flow FFF is becoming increasingly important with the wider use of membrane technologies. With this method, it is possible to investigate the fouling interactions between DOC and targeted membranes.

\section{Acknowledgements}

The support of University of Technology, Sydney (UTS) for the visit of Seunghyun Kim during the period of January, 2005 - January, 2006 is greatly appreciated. The first author sincerely appreciates the supports of Chancellor's postdoctoral research fellow grant and the Kwanjeong Educational Foundation for his scholarship. This work is partially funded by DEST international science linkage project and EUMBRA EU project. The third author would like to thank the Institute for Water and Environmental Resource Management and University of Technology, Sydney for his scholarship.

\section{References}


Aiken, G. R. and Malcolm, R.L., "Molecular weight of aquatic fulvic acids by vapor pressure osmometry,” Geochim. Cosmochim. Acta., 51, 2177 (1987).

Amy, G. L., Collins, M. R., Kuo, C. J. and King P. H., “Comparing gel permeation chromatography and ultrafiltration for the molecular weight characterization of aquatic organic matter,” J. Am. Water Works Ass., 79, 43 (1987).

Assemi, S., Newcombe, G., Hepplewhite, C. and Beckett, R., “Characterization of natural organic matter fractions separated by ultrafiltration using flow field-flow fractionation,” Water Res., 38, 1467 (2004).

ASTM, "Standard E11-95: Specification for wire cloth and sieves for testing purposes," American Society for Testing and Materials, West Conshohocken (1995).

Beckett, R., Jue, Z. and Giddings, J.C., "Determination of molecular weight distribution of fulvic and humic acids using flow field-flow fractionation,” Environ. Sci. Technol., 21, 289 (1987).

Beri, R. G., Hacche, L. S. and Martin, C. F., "HPLC: practical and industrial applications,” CRC press, $2^{\text {nd }}$ Ed., Washington D.C., Ch. 6, 315 (2001).

Bowen, W. R. and Mohammad A. W., "Characterization and prediction of nanofiltration membrane performance-A general assessment,” Trans IChemE, 76, 885 (1998).

Brock, T. D. “Membrane filtration,” Sci. Tech. Inc. (1983).

Buffle, J., Deladoey, P., Haerri, W., “The use of ultrafiltration for the separation and fractionation of organic ligands in freshwater,” Anal. Chem. Acta., 101, 339 (1978).

Buffle, J., Perret, D. and Newman, M., "The use of filtration and ultrafiltration for size fractionation of aquatic particles, colloids, and macromolecules.” In Environmental Particles. 1, eds. Buffle, J. and van Leeuwen, H.P. 171. Lewis Publishers, Boca Raton (1992).

Cai, Y., "Size distribution measurements of dissolved organic carbon in natural waters using ultrafiltration technique,” Water Res., 33, 3056 (1999).

Cameron, R. S., "Calibration of gel permeation chromatography materials for use with humic acid,” J. Soil Sci., 23, 342 (1972).

Chin, Y., Aiken, G. and O’Loughlin, E., "Molecular weight, polydispersity, and spectroscopic properties of aquatic humic substances,” Environ. Sci. Technol., 28, 1853 (1994). 
Cho, J, Amy, G. and Pellegrino, J., "Membrane filtration of natural organic matter: factors and mechanisms affecting rejection and flux decline with charged ultrafiltration (UF) membrane,” J. Membr. Sci., 164, 89 (2000).

Cho, J., "Natural organic matter (NOM) rejection by, and flux-decline of, nanofiltration (NF) and ultrafiltration (UF) membranes," $\mathrm{PhD}$ thesis, Department of Environmental Engineering, University of Colorado (1998).

Combe, C., Molis, E., Lucas, P., Riley, R. and Clark, M., "The effect of CA membrane properties on adsorptive fouling by humic acid” J. Membr. Sci., 154, 73 (1999).

Eaton, A. D., Clesceri, L. S. and Greenberg, A.E., "Standard methods for the examination of water and wastewater,” American Public Health Association, Washington, DC. (1995).

Gimbert, L. J., Andrew, K. N., Haygarth, P. M. and Worsfold, P. J., "Environmental applications of flow field-flow fractionation (FIFFF),” TrAC Trends in Analytical Chemistry, 22, 615 (2003).

Gimbert, L. J., Andrew, K. N., Haygarth, P. M. and Worsfold, P. J., "Environmental applications of flow field-flow fractionation (FIFFF),” TrAC Trends in Analytical Chemistry, 22, 615 (2003).

Gjessing, E. and Lee, G. F., "Fractionation of organic matter in natural waters on Sephadex column,” Environ. Sci. Technol., 1, 631 (1967).

Hartmann, R. L. and Williams, S. K. R., "Flow field-flow fractionation as an analytical technique to rapidly quantitate membrane fouling,” J. Membrane Sci., 209, 93 (2002).

Hassellöv, M., "Relative molar mass distributions of chromophoric colloidal organic matter in coastal seawater determined by Flow Field-Flow Fractionation with UV absorbance and fluorescence detection,” Mar. Chem., 94, 111 (2005).

Her, N. G, Amy, G., Foss, D., Cho, J., Yoon Y. and Kosenka P., "Optimization of mothod for detecting and characterizing NOM by HPLC-size exclusion chromatography (SEC) with UV and on-line DOC detection,” Environ. Sci. Technol., 36, 1069 (2002).

Her, N. G., "Identification and characterization of foulants and scalants on NF membrane," Doctoral thesis of philosophy, University of Colorado, 40, (2002). 
Her, N., Amy, G., Foss, D. and Cho, J., "Variations of Molecular Weight Estimation by HP-Size Exclusion Chromatography with UVA versus Online DOC Detection,” Environ. Sci. Technol., 36, 3393 (2002).

Huber, S. A. "Evidence for membrane fouling by specific TOC constituents,” Desal., 119, 229 (1998).

Huber, S. A., "Organics: the value of chromatographic characterization of TOC in process water plants,” Ultrapure Water, December, 16 (1998b).

ISO, “Technical requirements and testing. International Organization for Standardization,” Genève, (1990).

Kainulainen, T., Tuhkanen, T., Vartianinen, T., Heinonen-Tanski, H. and Kalliokoski, P., "The effect of different oxidation and filtration processes on the molecular size distribution of humic material,” Water Sci. Technol., 30, 169 (1994).

Kim, Y.M. and Koo, Y.M., "Separation of Mixed Solutes Using Reciprocating Size Exclusion Chromatography: Computer Simulation Based upon Experimental Parameters,” Korean J. Chem. Eng., 19, 663 (2002).

Lee, S., Park, G., Amy, G, Hong S. K., Moon, S.H., Lee, D.H. and Cho, J., “Determination of membrane pore size distribution using the fractional rejection of nonionic and charged macromolecules,” J. Membrane Sci., 201, 191 (2002).

Leenheer, J. A. and Croue, J.-P., "Characterizing aquatic dissolved organic matter," Environ. Sci. Technol., 37, 19A-26A (2003).

Lentsch, S., Aimar, P. and Orozco, J. L., "Separation albumin-PEG: transmission of PEG through ultrafiltration membranes,” Biotechnol. Bioeng., 41, 1039 (1993).

Levine, A. D., Tchobanoglous, G. and Asano, T., “Characterization of the size distribution of contaminants in wastewater: treatment and reuse implications,” Journal WPCF, 57, 805 (1985).

Logan, B. E. and Jiang, Q., "Molecular size distribution of dissolved organic matter," Journal of Environmental Engineering, 116, 1046 (1990).

Macko, C., "Ultrafiltration characterization of aquatic organics," Proc. AIChE Sym. Series, 75, 162 (1979).

Malpei, F., Rozzi, A., Collli, S. and Uberti, M., "Size distribution of TOC in mixed municipal-textile effluents after biological and advanced treatment,” J. Membrane Sci., 131, 71 (1997). 
Metcalf and Eddy, "Wastewater engineering - treatment, disposal and reuse,” $3^{\text {rd }}$, revised by G. Tchobanoglous and F. Burton, (1991).

Mulder, M., "Basic principles of membrane technology,” Kluwer Academic Publishers, $2^{\text {nd }}$ edition, Boston, USA, 18 (1996).

Novotny, F. J., Rice, J. A., Well, D. A. Abbtbraun, G., Kudryavtsev, A.V. and Hesse, S., "Development of a predictive model for calculation of molecular weight of humic substances,” Water Res., 32, 872 (1998).

Ogura, N., "Molecular weight fractionation of dissolved organic matter in coastal seawater by ultrafiltration,” Mar. Biol., 24, 305 (1974).

Painter, H.A., “Organic compounds in solution in sewage effluents,” Chem. Ind. September, 818 (1973).

Pelekani, C., Newcombe, G., Snoeyink, V. L., Hepplewhite, C., Assemi, S. and Beckett, R., “Characterization of natural organic matter using high performance size exclusion chromatography,” Environ. Sci. Technol., 33, 2807 (1999).

Pempkowiak, J. and Obarska-Pempkowiak, H., "Long-term changes in sewage sludge stored in a reed bed," Sci. Total Environ., 297, 59 (2002).

Poole, C. F., “The essence of chromatography,” Elsevier Science B.V. Netherland (2003).

Reid, P. M., Wilkinson, A. E., Tipping, E. and Jones, M. N., “Determination of molecular weights of humic substances by analytical (UV scanning) ultracentrifugation,” Geochim. Cosmochim. Acta., 54, 131 (1990).

Reszat, T. N. and Hendry, M. J., "Characterizing dissolved organic carbon using asymmetrical flow field-flow fractionation with on-line UV and DOC detection,” Anal. Chem. 77, 4194 (2005).

Schafer, A. I., "Natural organics removal using membranes: principles, performance, and cost,” Technomic Publishing Company, Inc., Pennsylvania, USA (2001).

Schnoor, J. L., “Trihalomathane yields as a function of precursor molecular weight," Environ. Sci. Technol., 13, 1134 (1979).

Shaw, P. J., De Haan, H. and Jones, R. I. “Applicability and reliability of gel filtration to study aquatic humic substances revisited; the effects of $\mathrm{pH}$ on molecular size distributions,” Environ. Sci. Technol., 15, 753 (1994). 
Shon, H. K., Vigneswaran, S., Kim, In S., Cho, J. and Ngo, H. H., "The effect of pretreatment to ultrafiltration of biologically treated sewage effluent: a detailed effluent organic matter (EfOM) characterization,” Water Res., 38, 1933 (2004).

Shon, H. K., Vigneswaran, S., Ben Aim, R., Ngo, H.H., Kim, In S. and Cho, J., "Influence of flocculation and adsorption as pretreatment on the fouling of ultrafiltration and nanofiltration membranes: application with biologically treated sewage effluent," Environ. Sci. Technol., 39, 3864 (2005).

Shon, H. K., Vigneswaran, S. and Snyder, S. A., "Effluent organic matter (EfOM) in wastewater: constituents, effects and treatment,” Crit. Rev. Env. Sci. Tec., In press (2006).

Shon, H. K., Vigneswaran, S. and Ngo, H. H., "Effect of partial flocculation and adsorption as pretreatment to ultrafiltration in treating wastewater,” AIChE Journal, 52, 207 (2006b).

Singh, S., Khulbe, K. C., Matsuura, T. and Ramamurthy, P., "Membrane characterization by solute transport and atomic force microscopy,” J. Membr. Sci., 142, 111 (1998).

Stevenson, E. J., “Colloidal properties of humic substances. Humus Chemistry,” Wiley Interscience, New York, (1982).

Stull, J. K., Swift, D. J. P. and Niedoroda, A.W. “Contaminant dispersal on the Palos Verdes continental margin: I. sediments and biota near a major California wastewater discharge,” Sci. Total Environ., 179, 73 (1996).

Swift, R. S. and Posner, A. M., "Gel chromatography of humic acid,” Journal of Soil Science. 22, 237 (1971).

Thurman, E. M. “Organic geochemistry of natural waters,” Martinus Nijhoff/Dr. W. Junk Publishers. The Netherlands (1985).

Thurman, E. M. and Malcolm, R. L., "Concentration and fractionation of hydrophobic organic acid constituents from natural waters by liquid chromatography,” USGS Water Supply Paper 1817-G (1979).

Thurman, E. M., Werhsaw, R. L., Malcolm, R. L. and Pinckney, D. J., “Molecular size of aquatic substances,” Org. Geochem. 4, 27 (1982). 
Tong, X. and Caldwell, K. D., "Separation and characterization of red blood cells with different membrane deformability using steric field-flow fractionation,” Journal of Chromatography B: Biomedical Sciences and Applications, 674, 39 (1995).

Xu, R., “Particle characterization: light scattering methods,” Kluwer Academic Publishers. The Netherlands, (2000).

Zanardi-Lamardo, E., Clark, C. D. and Zika, R. G., "Frit inlet/frit outlet flow field-flow fractionation: methodology for colored dissolved organic material in natural waters,” Analytica Chimica Acta, 443, 171 (2001).

Zanardi-Lamardo, E., Clark, C. D., Moore, C. A. and Zika, R. G., “Comparison of the Molecular Mass and Optical Properties of Colored Dissolved Organic Material in Two Rivers and Coastal Waters by Flow Field-Flow Fractionation,” Environ. Sci. Technol., 36, 2806 (2002).

Zhou, Q., Cabaniss, S. E. and Maurice, P. A., "Considerations in the use of high-pressure size exclusion chromatography (HPSEC) for determining molecular weights of aquatic humic substances,” Water Res., 34, 3505 (2000). 